\title{
The Colonial Evils Depicted in Joseph Conrad's Heart of Darkness
}

\author{
Md Masihur Rahman
}

\begin{abstract}
Written in the colonial context, Joseph Conrad's Heart of Darkness is a potential exploration of the nature of colonial evils and hypocrisy. Set in an atmosphere of gloomy darkness dominated by criminality towards humanity the narrator reveals his agonising experience and realisation regarding organised plunder of the colonial human/natural resources. The novella published in book format in 1902, is partly based on the writer's experience in the Congo basin where he was appointed a captain of a river steamer named Roi Des Belges in 1890 . The novella published during heyday of European colonialism represents in its multi-layered capacity some distinct forms of evils associated with Colonialism. As part of postcolonial study this article would like to explore forms of such colonial evils. Three distinct forms of evil are prominently found in the novella: the base, primitive instincts like lust and greed associated with individual take the shape of evil in some characters; the banality of ordinary mankind whose wilful silence and assumed denial helps the evil to grow; and the colonial European hypocrisy and trading secrets shows its evil aspects in Congo. Although Heart of Darkness has highlighted more the primitive and base evil, the other colonial evils have been depicted in its ugly shape through the images, metaphor and phrases in the novella. Going through these colonial evils this article would like to contribute to broader understanding of inclusive humanism.
\end{abstract}

Keywords: Evil, Colonial Site, Hypocrisy, Torture, Humanism.

\section{Introduction}

This section should be concise and define the background and significance of the research by considering the relevant literature, particularly the most recent publications. When preparing the introduction, please bear in mind that some readers will not be experts in your research field. While undertaking journey to visit a place of his childhood dream and fascination Conrad discovered how the place and its inhabitants are fast losing its lustre and it was transformed into a devil's playground. Congo was a childhood dream and its shocking revelation prompted him to write down and unmask the evils of colonial enterprise. The multi-layered text is rich in its depiction of Colonial evils manifested in multiple ways. Charles Marlow, the primary narrator, is seated aboard a yawl, Nellie, with his friends who are enjoying different position under the colonial rule: a Company Director, a Lawyer, an Accountant and an unidentified narrator who like Marlow, has much similarities with Conrad himself. They are enjoying each other's company. The atmosphere is gloomy. The narration of Marlow's strange and unfamiliar experiences made it gloomier. Firmly setting a sinister echo of the story at the outset of the novel that would hover in the air throughout the novel, Conrad probably hoped to bring the processing of evil before the readers. Marlow, seated in a 
Buddha like posture with legs crossed, back straight, arms dropped, palm in a prostrate mode started talking about his sojourn before the group of listeners. Evening darkness descends making the story teller a mystical body. Our narrator who is recollecting the whole thing before us is hypnotized. In fact, the narrator is feeling compelled to disseminate Marlow's story before the readers who would be awakened to a fresh way of ethical thoughts about Colonialism and its associated evils. Conrad's contribution to reformation and humanity lies in the understanding and depiction of the origin and nature of evil in Heart of Darkness: the primordial, corrupting and self-eroding temptation of evil inside the human heart; the darkness in the so-called progress of civilization and the banal evil found in decent and ordinary people like Marlow. Although there are other sources of evil found here, the novella is more fascinated with the primordial manifestation of evil.

\subsubsection{Historicizing the colonial evils depicted in "Heart of Darkness":}

During 1890's when Conrad was searching a job as captain to go to his dream point, there was headlines in London about the successful Emin Pasha Relief expedition of Henry Stanley ${ }^{1}$. Like Conrad everybody with some idea about Africa firmly believed about these highlighted campaigns which were assumed to be conducted to civilize and enlighten the ignorant people of Africa. According to Adam Hochschild, "in the nineteenth century European drive for possessions in Africa, people justified colonialism in various ways, claiming that it Christianized the heathen or civilized the savage races or brought everyone the miraculous benefits of free trade" (Hochschild 1999, p.38). The Victorian moral sensibilities took these noble causes heartily. Joseph Conrad was appointed captain ofa river steamer Roi Des Belges by a Belgian Trading Company. During his trip to Congo Conrad witnessed "evidence of atrocities, exploitation, inefficiency, and hypocrisy and it fully convinced him of the disparity of imperialism's rhetoric and the harshest reality" (Watts 1996, p.48) of looting. Conrad saw forced labour and corruption perpetrated by King Leopold II's agents in Congo ${ }^{2}$. According to Peter Eichstaedt, by taking Congo as his personal property where he was assumed to bring the lights of civilization, actually King Leopold II sets "in motion one of the most monstrous plunders ever by a colonial power. Ivory, gold, rubber and an array of minerals were taken in his name, along with millions of lives" (Eichstaedt 2011, p.1).

\subsubsection{Trip to Congo:}

Conrad's Congo trip for six months surely and firmly provided "a basis for the indignation" (watts, 1996, p-48). Conrad's trip "gives an authenticity that undoubtedly has contributed to its enduring power and appeal" (Firchow, 2002, p.22) According to Conrad's own words "Heart of Darkness is experience... pushed a little (and only very little) beyond the actual facts of the case" (Mongredien, 2011). Heart of Darkness has been instrumental in exposing to readers the atrocities unleashed by Leopold II's ${ }^{3}$ agents to extract and export the resources like Ivory and rubber "which may, in turn, account for the death of almost ten million Congolese natives" (Hochschild, 2005, p.40). Under the pretext of "white man's burden"4-the prevalent modus operandi, the Belgian colonialism robbed the people of its resource and culture. Such colonial policy is denigrated by Conrad through his mouthpiece-Marlow.

"the conquest of earth, which mostly means taking it away from those who have a different conception or slightly flatter noses than ourselves, is not a pretty thing when you look into it too much." (Conrad, 2008, p.107)

This passage shows Marlow's shocking revelation about assumed superiority based on physical differences. During his trip to Congo Marlow witnessed the brutalities in many forms. While passing a railway construction site Marlow saw the abominable nature of colonialism.

"A slight clinging behind me made me turn my head. Six black men advanced in a file 
toiling up the path. They walked erect and slow, balancing small baskets full of earth on their heads, and the clink kept time with their footsteps... I could see every rib, the joints of their limbs were like knots in aa rope, each had an iron collar on his neck and all were connected together with a chain whose bights swung between them, rhythmically clinking" (Conrad, 2008, p.116)

Marlow is appalled to see the dehumanization of the native people to set the footprint of progress in that region. Phrases like "every rib" and "the joints...were knots in a knob" (p.116) shows the poor health condition of these people. These people have been chained like animal to get the work done. King Leopold II considered such forced labour "the only way to civilize and uplift these indolent and corrupt peoples of the far east" (Hochschild,1999, p.37). To his shocking revelation he saw some of these people who crawled away to the grove of death to die. He also noticed "now and then a carrier dead in harness, at rest in the long grass near the path, with an empty water gourd and his long staff lying by his side"(Conrad, 2008, p.121).Again, Marlow observes the "body of a middle-aged negro with a bullet hole in the forehead" (Conrad, 2008, p.121). He can hear the screaming of a negro boy being beaten up to accidentally causing a fire: "A nigger was being beaten up nearby. They said he had caused the fire in some way... he was screeching horribly" (Conrad, 2008, p.125). Images have been portrayed to show instances of how people were terrified about forced labour

"The population had cleared out long time ago. Well if a lot of mysterious niggers armed with all kinds of fearful weapons suddenly took to travelling on the road in England between Deal and Gravesend catching the yokels right and left to carry heavy loads for them, I fancy every farm and cottages thereabouts would get empty very soon... I passed through several abandoned villages" (Conrad, 2008, p.121).

\subsubsection{Economic exploitation:}

Again, from Marlow's speech the economy of Congo reflects the exploitation. "A stream of rubbishy cottons, beads and brass wire (were sent) into the depths of darkness and in return came a precious trickle of ivory" (Conrad, 2008, p.119). Ironically "ivory rang in the air, was whispered, was sighed. You should think they were praying to it" (Conrad, 2008, p.125). Ivory constituted the core area of Congo economy before the discovery of rubber and other minerals. Every agent cum trader would dream of collecting ivory from a trading post "where ivory was to be had, so that they could earn the percentages" (Conrad, 2008, p.126). This line indirectly refers to the system of commissions offered to the agents of king Leopold to increase the dynamics of extracting ivory using the native people.

\subsubsection{Company Agents:}

In this connection Conrad has represented the image of the "lone white agent far up the great river, with his dreams of grandeur, his great store of precious ivory, and his fiefdom curved out of African jungle" (Conrad, 2008, p.164). The character of Kurtz brings an image of agent lurking in the darkness of colonialism. The dark force of colonialism left him unrestrained. A character comments about Kurtz- "you cannot judge Mr. Kurtz as you would an ordinary man" (Conrad, 2008, p.162). Certainly "all Europe contributed to the making of Kurtz" (Conrad, 2008, p.154). And this character is an example of colonial European who have brought an unknown inhuman behavior that seared the soul of the continent (Eichstaedt,2011, p.211). One can argue that Kurtz is an evil incarnation of King Leopold II and his devilish greed of colonial expansionism in Congo.

Kurtz's character was probably made out of real-life agents. It may be inspired by Leon Rom because when Conrad was "passed through Leopoldville, the station chief there was Leon Rom"(Hochschild,1999, p.147) The dried severed heads on the fencing post surrounding the house of Kurtz with their "heads on the stakes...(looking) black , dried, sunken, with closed eyelids"(Conrad, 2008, p.164) is a reminiscent of Captain Rom whose bed was similarly decorated with the severed heads of Congolese people who refused to 
comply with Kurtz's order or failed to touch the quota of ivory. Whispering the words "The Horror! The Horror!" (Conrad, 2008, p.178) Kurtz metaphorically expressing the brutalities and horror experienced by the Congolese people who faced the extermination /working to death. These people were "virtually enslaved and cruelly maltreated in the quest for ivory." Kurtz's is a colonial product because "all Europe contributed to the making of Kurtz" (Conrad, 2008, p.154). He is half English and half French. His ancestry is symbolical of colonial powers.

\subsubsection{Evils in Abstract Forms:}

Historicizing the atmosphere of the novel certainly some thoughts may surface to conceptualize the depiction of evils in abstract terms. Conrad's title of the novel- "Heart of Darkness" drives us to glean the idea of evil lurking and working everywhere in the novel. The historical context, fictional atmosphere and the characters along with their thought process bring the working of evils at several levels. The personal motives of some characters bring to the fore the primitive evils of human beings like lust and greed reflected in the character of Kurtz. The policy and decisions adopted by the trading company to exploit the native people of their resources constitute colonial evils manifested in the exchange of brass wire and ivory. Again, Marlow's willful silence and promotion of tortures under the garb of protecting woman from bitter facts constitute the banality of evils. Eventually different manifestation of evils merges together under the big banner of Colonialism.

\subsubsection{Primitive Evil:}

Marlow broods over human nature and its conditioned activities. He is also projecting civilization as a disciplined system where powerful negative desires and dark impulses are chained. The antihero Kurtz became savage while roaming in the assumed first ages as he gets disconnected from the disciplined system of civilization or the restraining voices of the disciplined public, neighbors and family members. Being immersed in a sense of superiority due to his European origin, the evil aspects of his soul got the upper hand and consumed his civilized self.

Kurtz, disconnected from civilized way of life was fated to assume "a high seat among the devils of the land." (Conrad, 2008, p.154) Marlow is informed by someone about Kurtz presiding at "at midnight dance ending with unspeakable rites, which as far as I reluctantly gathered from what I heard at various times-were offered up to him-do you understand-to Mr. Kurtz himself'.(Conrad, 2008, p. 155) This devilish manifestation of evil is like falling in love with evil. The devilish and irrational behavior of these Europeans left an indelible mark on Conrad's memory and imagination. Through the portrayal of the perversion of Kurtz, Conrad seems to have drawn our attention to the different and peculiar construction/manifestation of evil. He writes,

"what I distinctly admit is the fault of having made Kurtz too symbolic or rather symbolic at all. But the story being mainly a vehicle for conveying a batch of personal impressions, I gave reign to my mental laziness and took the line of learnt resistance" (Kimbrough 10).

Kurtz's malpractices are directly linked with barbaric self. Conrad seems to suggest that the severing of heads or hands of colonized people or even the collection of their skull- the European mode of atrocities did all of that in an agonized way-but rather executing the same thing in uncivilized rituals of lust and self-aggrandizement.

\subsubsection{Evil at The Heart of Civilization:}

King Leopold's rule was distinctly marked by innocent killing, forced labor, torture and the spread of disease and famine. Hands would be cut off in some cases to save bullets. These 
severed hands were mostly visible at the posts along the river. Around 10 million Congolese were killed for their personal profit during the period of 1885 and 1908(Jones,2006). In response to torture, killing and maiming of Congolese, Congo Reform Association was formed owing to the tireless service of Edmund Dene Morel, the founder of the association. Journalistic accounts documenting Human Rights abuses were widely circulated among the European people. Some contemporary literary figures like Mark Twain wrote critical comments criticizing Leopold's cruelties.

Marlow could hear the buzzing sound of entrepreneurship and profits when he was preparing himself for Africa. He could hear talks about the inferiority of native people and "white man's burden" to bring lights of Civilization to African people ${ }^{4}$. These talks along with the indistinct and hazy talks about business and personal gains began to make Marlow feel uneasy. In a way this prefigures subsequent discourse of the fierce plundering of the resource of Africa and African native. Conrad has contributed to humanity by divulging the secrets of exploitation in the name of trade and business to his wide readers. He has rightly pointed out that dark sides of Empire and the darkness at the heart of Civilization.

The idea of cultural relativism is also manifested in the novel. This observation is clear when he speaks of Britain that it (Britain) too "had been one of the dark places of the earth" (Conrad, 2008, p. 105). London, the Centre of world's largest Empire was once an uncivilized territory. The advanced soldiers and politicians and religious scholars of Roman empire made their way into Britain and forced the uncivilized and savage, primitive and hostile natives to surrender before him. Through his mouthpiece Conrad concludes that burden of the progress of a civilized territory requires an extension of cultural light to public living in darkness but Marlow experiences foolish and aimless railway and industrial activities, misuse of machines and human resources, the indigenous people beaten and killed, worked to death in chain gangs. He finds "a flabby, pretending, weak eyed devil of a rapacious and pitiless folly" (Conrad, 2008, p.117). The European people we find in Heart of Darkness except Marlow are either agents of devil or greedy travelers/pilgrims. In a way Conrad was reminded of "Russian Empire which destroyed his family and ravaged his childhood" (Fincham and Myrtle,1996, p.43).

Some journalistic works are found revealing the Congolese life. William Sheppard, Roger Casement, George Washington Williams have recorded their experiences to address the issues and raise the European consciousness about the realities of colonial life. We can see some literary presentation which seem to be connected to Conrad's 'Congo Diaries' which include the bodies of several dead Africans, one who had been shot; another in a meditative mode sitting on a road; again a mere skeleton of human body found tied up to a pole (near) the grave of an unnamed white European; Heap of stones formed a cross. Marlow stands different from the other Europeans. In the novel we find him recognizing the humanity of all people irrespective of their colour, his self-restraint and his awareness of the intelligence/virtue of simplicity of the native people.

\subsubsection{Banal Evil:}

While successfully dealing with the situations arising out of the demise of Kurtz Marlow becomes involved in lies although his initial comment - "I hate, detest and can't bear a lie... There is a taint of death, a flavor of mortality in lies-which is what I exactly hate and detest in the world what I want to forget" (Conrad, 2008, p.129) was opposite. During his meet with Kurtz's unnamed intended, after his return from Africa, he consciously dealt with lies to hide the true face of European's "Devil of rapacious and pitiless folly" (Conrad, 2008, p.117) as well as Kurtz who was aligned with the evil. In response to Kurtz's unnamed intended's inquiry into the last expression of Kurtz, Marlow does injustice with the innocent woman practically hiding the truth. Marlow informs her that "the last word he pronounced was- your name" (p. 186). 
Such white lie was made to lead a livable life. The truth seemed to him too dark to share. But to keep the bitter truth hidden from ordinary European's consciousness is also promoting silence and willful denial of colonial cruelty. this white lie is an instance of Marlow's Chauvinism and racism. Chauvinism because Marlow wanted to keep the truth away from women. Racism because it was promoting indifference toward the plight of Congolese people. The women and the common people remain ignorant of what was going on in Congo.

Marlow's companions were also involved in the same profession. Marlow's personal experience did not influence his friends except the secondary narrator. Again, Marlow's complicity in hiding the colonial criminalities is shared in different place and at a different time. Such banal complicity is generally seen as ordinary and casual. By lying, Marlow is engaged in subordination of human values. the necessity to talk openly about evil and criminal activities is subordinated to the necessity of being kind and gentle. In this way a status quo of an undisturbed life is maintained and evils are promoted.

\section{Conclusion}

Thus, Heart of Darkness successfully deals with several forms of evils relating to colonialism and Conrad's presentation of a trip to colonial world unmasks and bares open the camouflage of colonialism. The dark mysterious atmosphere hovering in the novel is none other than the construction of evils. Personal evil tendencies took a wild turn in a colonial setting. The banal complicity very complacently employs silence and willful denial to grow the branches of evil in the ordinary human heart. Civilizational superiority and western notion of progress and enlightenment have also been questioned showcasing the battering and crumbling structure of humanism in a colonial perspective. The failure to maintain basic moral standard is very much incompatible with so called "white man's burden"4. Conrad's Inclusive humanism expects to unearth such constructions of evils to have a broader understanding. By participating in the process of discovery of colonial reality, its hypocrisy and treatment of the native people Heart of Darkness is necessarily a novel depicting/ representing different facets of colonial evil.

\section{Notes}

1. Henry Morton Stanley explored the Congo Basin at the invitation of Belgian King Leopold II, which led to establish the Congo Free State-A personal property of Belgian King Leopold II.

2. For detailed information on Conrad's visit to Congo see Robert Hampson (ed.), Joseph Conrad: "Heart of Darkness" with "the Congo Diary" (London: Penguin,1995)

3. For more information on King Leopold II, see Hochschild, A. (1999). King Leopold's Ghost: A Story of Greed, Terror and Heroism in Colonial Africa. New York: Houghton Mifflin Harcourt.

4. "White Man's Burden" - A poem by Rudyard Kipling is generally interpreted to mean that white people have a moral obligation to rule over the other, especially black, people in order to civilize and develop them so that they become enabled to take their place economically and socially.

\section{References}

Conrad, J. (2008). Heart of darkness. Ed. Cedric Watts. Oxford University Press.

Eichstaedt, P. (2011). Consuming the Congo: War and Conflict Minerals in the World's Deadliest Place. Chicago Review Press.

Fincham, G., \& Myrtle, H. (1996). Under Postcolonial Eyes: Joseph Conrad after Empire. Juta and Company Ltd.

Firchow, P.E (2000). Envisioning Africa: Racism and Imperialism in Conrad's Heart of Darkness. University Press of Kentucky. 
Hochschild A (1999). King Leopold's ghost: a Story of greed, terror, and heroism in colonial Africa. Mariner Books.

Jones, A. (2006): A Comprehensive Introduction. Routledge. http://dx.doi.org/10.4324/9780203347447

Kimbrough, R (1988). Introduction to Joseph Conrad's heart of darkness. Norton.

Mongredien P. (2011). "Heart of Darkness Review" https://www.theguardian.com/books/2011/jan/23/heart-of-darkness-conrad-review

Watts, C. (1996). "Heart of Darkness" (ed.) by J.H. Cambridge Companion to Joseph Conrad, p.45-63. Cambridge University Press.http://dx.doi.org/10.1017/CCOL0521443911.003

\section{Bio-note}

Md Masihur Rahman is an Assistant Professor of English at Sukanta Mahavidyalaya, Dhupguri, Jalpaiguri, West Bengal. He has completed his masters from TM Bhagalpur University. His areas of interest are- Postcolonial Theory and Praxis, Indian writing in English, Subaltern study, Dalit Literature.

Email- mdmasihur84@gmail.com 